\title{
Seasonal evolution of aerosol stratigraphy in Ürümqi glacier No. 1 percolation zone, eastern Tien Shan, China
}

\author{
WANG Feiteng, LI Zhongqin, YOU Xiaoni, LI Chuanjin, LI Huilin, LI Xiangying, \\ ZHU Yuman
}

Laboratory of Cryosphere and Environment/Tien Shan Glaciological Station, Cold and Arid Regions Environmental and Engineering Research Institute, Chinese Academy of Sciences, 320 Donggang West Road, Lanzhou 730000, China E-mail: qianj@Izb.ac.cn

\begin{abstract}
The processes involved in the evolution of vertical profiles of $\mathrm{Mg}^{2+}, \mathrm{Ca}^{2+}$ and microparticle concentrations, as well as their seasonal variation in surface snow, were studied by weekly sampling from September 2003 to September 2004 of a snow pit on Ürümqi glacier No. 1, eastern Tien Shan, China. The development of the microparticle and $\mathrm{Mg}^{2+}$ and $\mathrm{Ca}^{2+}$ stratigraphy in the snow pit is closely related to the physical development of the snow-firn pack. The sampling site is located at $4130 \mathrm{~m}$ a.s.I. in the percolation zone of the glacier, and in addition to the effects of sublimation and wind erosion, melting plays a crucial role in both the physical and chemical evolution processes. During the winter, soluble aerosol concentrations in the surface layers are altered slightly by sublimation and wind erosion, and the concentrations are further modified as the wet season begins in late April. In contrast, soluble aerosol stratigraphy in the deeper layers remains relatively unchanged through the winter. In early summer, as melting occurs in the upper part of the snow-firn pack, meltwater carries chemical species to different depths in the underlying snow-firn layers, such that at the end of the ablation season, all of the surface cations might be leached out from the upper layers. In addition, the possible source of calcium and magnesium is discussed in this paper.
\end{abstract}

\section{INTRODUCTION}

Ice-core chemistry records contain climatic and environmental information over a wide range of timescales. The records preserved in glaciers, however, are determined not only by the atmospheric concentration of the physical and chemical species and the processes involved in their deposition, but also by post-depositional processes such as melting, percolation, sublimation, wind filtration through firn (which involves mass loss, addition and/or exchange) and diffusion (Dibb, 1996; Waddington and others, 1996; Wolff, 1996; Ginot and others, 2001; Stichler and others, 2001; Schotterer and others, 2004; Schulz and de Jong, 2004).

In order to better understand the deposition and postdepositional processes controlling the chemical signals recorded in glacial snow and ice, the Program for Glacier Processes Investigation (PGPI) has examined the seasonal variation and evolution of $\mathrm{Mg}^{2+}, \mathrm{Ca}^{2+}$ and microparticle concentrations in 54 profiles collected over 12 months from a snow pit on Ürümqi glacier No. 1 (UG1), located in the eastern Tien Shan, northwestern China. Several similar studies have been accomplished on other alpine glaciers, (e.g. Psenner and Nickus, 1986; Neftel and others, 1987; Puxbaum 1989; Maupetit and others, 1993; Kuhn and others, 1998; Winiwarter and others, 1998; lizuka and others, 2002; Pohjola and others, 2002; Schotterer and others, 2004), but only a few studies (Hou and Qin, 1996, 1999; Hou and others, 1999) have been conducted in this region of the Tien Shan.

\section{THE SETTING AND GLACIOLOGY OF THE SAMPLING SITE}

UG1 is located at the Ürümqi riverhead adjacent to the vast deserts and dried lakes of central Asia and far from densely populated areas. The glacier itself is composed of east and west branches which flow around a mass of exposed bedrock and moraine sediment, the chemical composition of which is rich in such species as sodium, calcium, magnesium and iron (Luo, 1983). The prevailing westerlies flow over the mountain range, but the topography distorts the wind flow into cyclonic and anticyclonic circulation patterns up to $4000 \mathrm{~m}$ a.s.l. Near the surface, the local valley winds prevail from March through September (Zhang and others, 1994). Typically, $90 \%$ of the precipitation in this region occurs between May and September.

From 1959 to 2003, the annual equilibrium-line altitude (ELA) of the glacier has averaged approximately $4055 \mathrm{~m}$ a.s.I. An observation and experimental site was carefully chosen in a percolation zone of the east branch of UG1 (where the ice surface slopes about $6^{\circ}$ ) above the ELA at 4130 ma.s.I. Here the overshadowing of the mountain ridges prevents direct exposure to sunshine in the winter. During the sampling period, the mean annual air temperature was about $-9.1^{\circ} \mathrm{C}$, and the precipitation, i.e. snowfall, was approximately $700 \mathrm{~mm}$ w.e.

The stratigraphic sequence of the pit from top to bottom can be described as fresh snow, coarse-grained snow, finegrained firn, firn and coarse-grained firn. The fresh snow and coarse-grained snow were derived from the accumulation of the most recent year, while the underlying firn layers were from previous years. The floor of the pit was made of 'infiltration-congelation ice' (Shumskii, 1964), or superimposed ice (Paterson, 1994), which was characterized by clear and impermeable opaque ice with spherical bubbles $\sim 1-5 \mathrm{~mm}$ in diameter. The depth typically ranged from about $1.5 \mathrm{~m}$ when the study began in the late summer to about $3 \mathrm{~m}$ in the late spring, but during the winter it remained stable because of snow compaction, drifting and sublimation. In the early summer, as air temperature rose to $\sim 0^{\circ} \mathrm{C}$, the upper part of the snow layer began to melt, which 

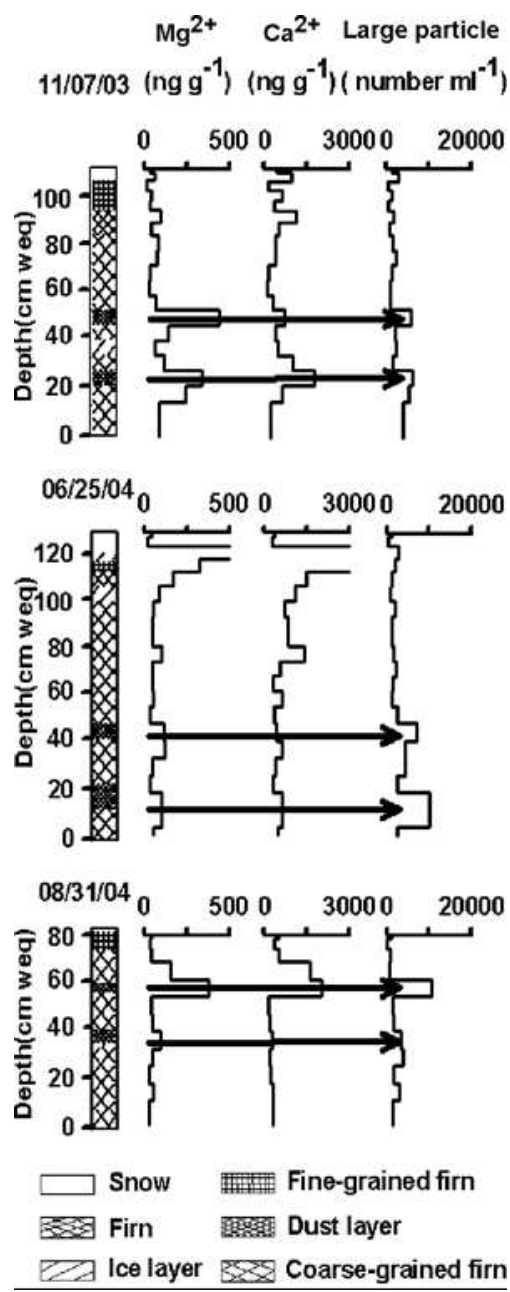

Fig. 1. The relationship between the snow stratigraphy and the $\mathrm{Mg}^{2+}, \mathrm{Ca}^{2+}$ and large particle concentration profiles in the snow pit on selected sampling days (dates are $\mathrm{mm} / \mathrm{dd} / \mathrm{yy}$ ). These profiles were selected from among the 54 that were created from the weekly sampling in order to illustrate seasonal changes. The $y$ axis presents height ( $\mathrm{cm}$ w.e.) above the surface of the superimposed ice.

led to a rapid thinning. The melting primarily involved the accumulation from the previous autumn. During the late summer to the early autumn, the melting impacted the entire annual layer, and even included the underlying accumulation from the previous year. The meltwater infiltrated to the underlying firn layers, reaching the impermeable superimposed ice formed the previous year. The water filled the pores and was refrozen to form new superimposed ice, while some of the meltwater pooled on the ice surface and eventually drained off.

\section{METHODOLOGY}

At the PGPI site, both surface snow and snow-pit samples were collected from September 2003 to September 2004 on a weekly basis. We tried to collect the fresh snow and wellpreserved surface snow (i.e. snow that was not affected by post-depositional processes such as sublimation or melting) at the sampling site each week to investigate the chemical seasonality in precipitation and dry deposition. Therefore, during the winter season when there was insufficient snowfall, we usually sampled the topmost $3 \mathrm{~cm}$. However, if an accumulation event occurred prior to the sampling, we collected the top $1 \mathrm{~cm}$ of the fresh snow. During the summer, there was usually sufficient fresh snow available, and samples from accumulation that was no more than 2 days old were usually collected from the top $3-5 \mathrm{~cm}$. Over the year a total of 54 surface snow samples were retrieved, but 9 samples were discarded for analysis because of problems associated with in situ melting.

The pit was also sampled from top to bottom at $10 \mathrm{~cm}$ increments 54 times during the year on a weekly basis to yield a total of 1011 samples. After each session, the pit was refilled and 7 days later was re-excavated. The wall was then scaled back by at least $50 \mathrm{~cm}$ before the next round of collecting. A strict protocol was followed during this procedure to prevent contamination, including the use of disposable polyethylene gloves, masks and pre-cleaned polyethylene sample containers. All the samples were transported in insulated boxes to the Tien Shan Glaciological Station (TGS) laboratory, and were kept frozen until analysis.

Insoluble particles, $\mathrm{Ca}^{2+}$ and $\mathrm{Mg}^{2+}$ were analyzed in the TGS laboratory. All sample handling was done in a class 100 clean room in order to minimize contamination. The $\mathrm{Ca}^{2+}$ and $\mathrm{Mg}^{2+}$ concentrations were measured by ion chromatography using a Dionex DX-320 system with a CS12A separation column. The detection limits of $\mathrm{Mg}^{2+}$ and $\mathrm{Ca}^{2+}$ are 0.8 and $0.75 \mathrm{ngg}^{-1}$, respectively (Zhao and Li, 2004). Microparticle concentrations and size distributions were measured with an AccuSizer 780A which uses Single Particle Optical Sensing (SPOS) technology and measures in 8-512 size channels, with an error of $<5 \%$ in the $0.5-$ $400 \mu \mathrm{m}$ measuring range. Prior to analysis, samples were melted at room temperature while the pipeline and AccuSizer system were cleaned with Milli-Q water until the background particle count was $<50 \mathrm{~mL}^{-1}$.

\section{RESULTS AND DISCUSSION}

\section{Processes involved in the post-depositional modification of the aerosol stratigraphy}

Although the processes involved in the post-depositional modification of the insoluble and soluble aerosols were different, the stratigraphy of the pits indicates that the dust layers occurred coincidentally with increases in $\mathrm{Ca}^{2+}$ and $\mathrm{Mg}^{2+}$, which suggests that these species were not leached out from the dust. The linear correlation coefficient $(r)$ of each ion with the large particles $(>10 \mu \mathrm{m}$ in diameter) is significant; for $\mathrm{Mg}^{2+}, r=0.74$ and for $\mathrm{Ca}^{2+}, r=0.85$ (twotailed, $p=0.01, N=107)$. Slight seasonal differences in the microparticle, $\mathrm{Mg}^{2+}$ and $\mathrm{Ca}^{2+}$ concentrations in the surface snow may be due to the aerosols being derived from separate sources. However, after being deposited into the snow, they experienced post-depositional alteration mainly controlled by meltwater percolation. It was determined that the development of the aerosol stratigraphies was closely related to the physical development of the snow-firn pack such that both experienced a similar evolution process (Fig. 1).

Figure 2 illustrates the evolution processes of the $\mathrm{Mg}^{2+}$ in the snow pits from September 2003 to September 2004 (the evolution processes of $\mathrm{Ca}^{2+}$ and microparticles in the snow pit are identical to $\mathrm{Mg}^{2+}$ ). In mid-September 2003, there were three marked $\mathrm{Mg}^{2+}$ peaks (P1, P2 and P3) in the firn at heights of 89,62 and $34 \mathrm{~cm}$, respectively, above the 


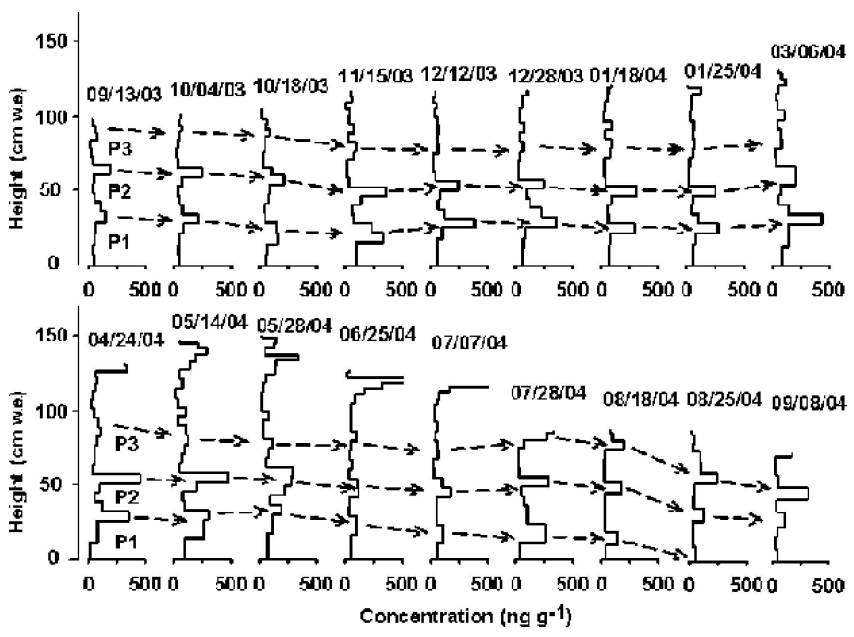

Fig. 2. The evolution process of vertical profiles of $\mathrm{Mg}^{2+}$ in snow pits from 13 September 2003 to 8 September 2004 (dates are mm/ $\mathrm{dd} / \mathrm{yy}$ ). P1, P2 and P3 indicate $\mathrm{Mg}^{2+}$ concentration peaks. The $y$ axis presents the height ( $\mathrm{cm}$ w.e.) above the surface of the superimposed ice. The September 2003 superimposed ice height $(0$ as plotted here) remained constant until approximately mid-June 2004, when the height increased as new ice was added by refreezing of percolating meltwater. These profiles were selected from among the 54 that were created from the weekly sampling in order to illustrate seasonal changes.

superimposed ice. From mid-September to mid-November 2003, P1, P2 and P3 moved downward to heights of 80, 55 and $16 \mathrm{~cm}$, respectively, from the bottom of the pit, and this movement was mainly related to snow compaction. During the period mid-November 2003 to late April 2004, several small concentration peaks appeared in the upper part of the snow pits. These resulted from limited precipitation, low temperatures and weak evaporation (Ginot and others, 2001; Stichler and others, 2001; Schulz and de Jong, 2004) at the site, which enabled post-depositional processes such as sublimation and dry deposition to become more dominant. As the temperature increased from April to late May, meltwater appeared in the pit, which attenuated the peaks as they moved downward. At the same time, the increasing precipitation resulted in successive concentration peaks at about $10-30 \mathrm{~cm}$ below the surface. In the summer (June-August), as meltwater percolated through the pit, it leached the ions, including $\mathrm{Ca}^{2+}$ and $\mathrm{Mg}^{2+}$ (Brimblecombe and others, 1985, 1987; Tranter and others, 1992; Eichler and others, 2001). During this period, the upper part of the snow pit experienced the most post-depositional alteration. With increasing temperature, larger volumes of meltwater began to percolate deeper into the pit along with the $\mathrm{Mg}^{2+}$, which is indicated by the displacement and reduced concentration of the peaks. When the water encountered the superimposed ice in the bottom of the coarse-grained firn layer, it refroze, resulting in accretion (mass gain) at the superimposed ice surface. This strong ablation caused the melding of the P3 layer with the surface layers. At the end of August, P1 merged into the superimposed ice at the bottom of the pit and was henceforth preserved in the glacier. By the beginning of September 2004, there were only two peaks observed in the snow pit. This demonstrates that in spite of considerable loss of $\mathrm{Mg}^{2+}$ through post-depositional processes, the general information is still preserved.

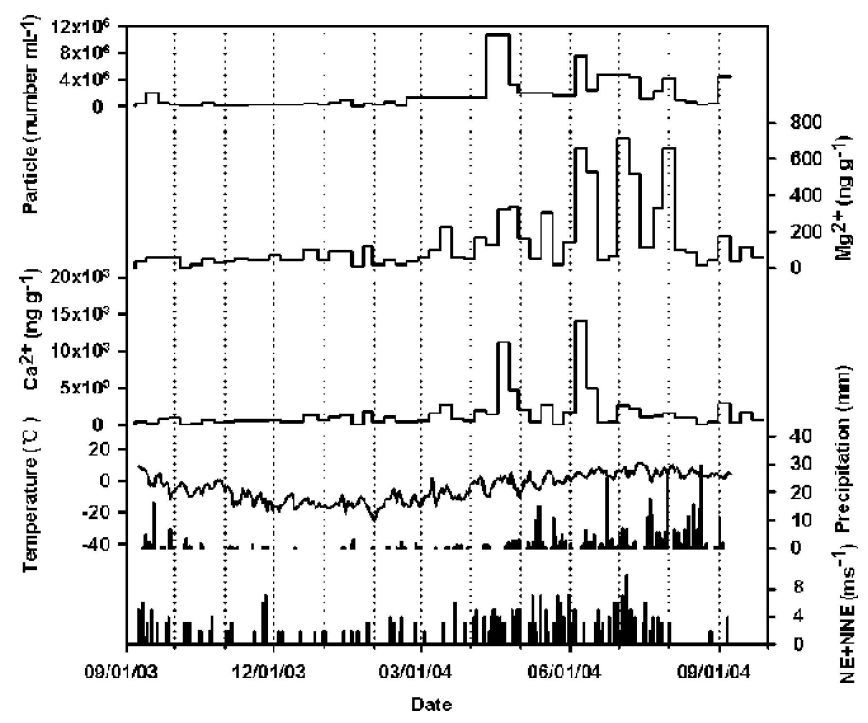

Fig. 3. Seasonal changes in calcium, magnesium and insoluble particle concentrations in surface snow and daily variability of temperature, precipitation and the prevailing wind speed vs time from September 2003 to September 2004 recorded at the Daxigou meteorological station. Dates are $\mathrm{mm} / \mathrm{dd} / \mathrm{yy}$.

\section{Seasonal variations of dust, $\mathrm{Mg}^{2+}$ and $\mathrm{Ca}^{2+}$ in the surface snow}

Dust and chemical species are removed from the atmosphere through dry and wet deposition (Heather and others, 2004). For both types of deposition, precipitation and wind are the main control factors on UG1. Once aerosols accumulate on the glacier surface, they undergo postdepositional alteration, which is mainly influenced by temperature and meltwater percolation. Surface samples collected from the uppermost $1-5 \mathrm{~cm}$ of surface snow were examined to investigate the chemical seasonality in precipitation and dry deposition (Fig. 3). The concentrations of all three species were low from October to the end of March, then were elevated from April to June. After that, they show different characteristics: $\mathrm{Ca}^{2+}$ rapidly decreased in June, but $\mathrm{Mg}^{2+}$ and, to a lesser extent, dust peaked along with August snowfall.

Data from the Daxigou meteorological station (3539 ma.s.l.), located $3 \mathrm{~km}$ away from UG1, show that the atmospheric stability, temperature, local valley wind strength and the precipitation were related to the insoluble and soluble aerosol concentrations in the surface snow. This can be seen in Figure 3 where the peak in surface snow concentrations is associated with wind-speed peaks and the precipitation. The high concentrations between May and June may be attributed to the local valley wind, which could potentially cause more dust input into the atmosphere and result in increased $\mathrm{Ca}^{2+}$ and $\mathrm{Mg}^{2+}$ concentrations. The juxtaposition of high dust and $\mathrm{Mg}^{2+}$ concentrations in July and August 2004 may have been due to the transport of these species from remote areas by moisture advection, which suggests that the $\mathrm{Mg}^{2+}$ concentration in the surface snow may be related to the dust coming from these remote regions. In winter, the low concentrations coincide with the temperature inversions and stable atmospheric stratification, similar to conditions that are observed in the Alps (Maupetit and others, 1995; Kuhn and others, 1998). 


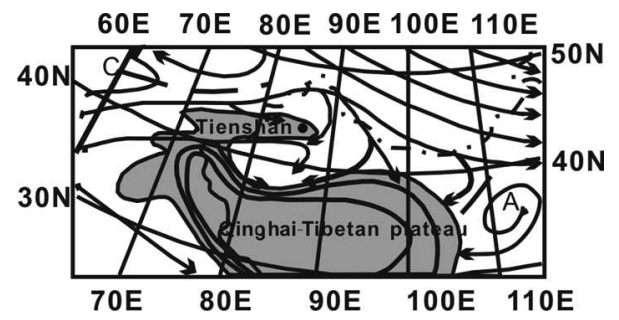

Fig. 4. Mean air-mass trajectory at $1500 \mathrm{~m}$ above the Tien Shan and surrounding areas during the spring season from 1960 to 1969 (modified from $\mathrm{Li}, 1991$ ). The location of the study site is indicated by the black circle. ' $\mathrm{A}$ ' indicates anticyclone, ' $\mathrm{C}$ ' indicates cyclone and the dashed line is national boundaries.

\section{Possible sources of $\mathrm{Ca}^{2+}$ and $\mathrm{Mg}^{2+}$}

The sources of the $\mathrm{Ca}^{2+}$ and $\mathrm{Mg}^{2+}$ in UG1 can be assessed by examining the correlation between various ions in the snow, as well as the atmospheric circulation pattern that brings moisture to the region. Based on the correlation matrix of ions captured from the surface snow at the site, we observe that the linear correlation of $\mathrm{Ca}^{2+}$ with electric conductivity and $\mathrm{pH}$ is 0.97 and 0.77 , respectively (twotailed, $p=0.01, N=45$ ). This indicates that the main components of the atmospheric dust are calcium-rich minerals, which probably come from the weathering of local rocks, as well as from the surrounding desert. Magnesium and dust are significantly correlated $(R=0.74)$ (two-tailed, $p=0.01, N=45$ ), which suggests that the $\mathrm{Mg}^{2+}$ source is more distant and may be mainly related to precipitation events.

Prevailing westerlies dominate the air circulation over the study area (Fig. 4), and westerly winds are especially dominant over the eastern Tien Shan when the circumArctic vortex is stronger (Zhang and Deng, 1987; Hu and Jiang, 1989; Qiu, 1993; Jiang and others, 2002). Therefore, moisture travels through this region from west to east. Along with this pattern of atmospheric circulation, the aerosols, which include $\mathrm{Mg}^{2+}$ and $\mathrm{Ca}^{2+}$, are blown from the inland deserts and transported to the study area by this strong airflow. This suggests that long-range transport accounts for part of the $\mathrm{Ca}^{2+}$ that is present in the snow pits.

\section{SUMMARY}

Long-term $\mathrm{Mg}^{2+}, \mathrm{Ca}^{2+}$ and microparticle data from snow pits were examined to determine the depositional and postdepositional processes that occur on UG1. During the winter, the formation of the vertical stratigraphy of the microparticle, $\mathrm{Mg}^{2+}$ and $\mathrm{Ca}^{2+}$ concentrations in the upper layers of the glacier was mainly related to snow compaction, sublimation and dry deposition. During the summer, the snow in the pit experienced the maximum post-depositional alteration through the percolation of the meltwater; however, alteration deeper in the snow pit was very slight and the general information was still preserved.

The seasonal changes in the concentrations of calcium and magnesium in surface snow display a characteristic sequence of low and high values. Low values of $\mathrm{Ca}^{2+}$ and $\mathrm{Mg}^{2+}$ were observed during the winter from November to April. The concentrations increased in May to several times those of the winter, peaked in June and then rapidly decreased through August. Through the autumn the concentrations appear to have been stable. The possible sources of $\mathrm{Ca}^{2+}$ may primarily be the local rocks and secondarily from a more remote source, while $\mathrm{Mg}^{2+}$ may be primarily from a remote source.

\section{ACKNOWLEDGEMENTS}

This research was supported by the National Natural Science Foundation of China $(40371028,40571033,40121101)$ and the Cold and Arid Regions Environmental and Engineering Research Institute (CACX2003101). We also thank P. Ginot, D. Hardy and an anonymous reviewer for useful comments and helpful suggestions, and M. Davis and T. Mashiotta for language editing. Support for this research has been provided under the Program for Glacier Processes Investigation conducted by the Tien Shan Glaciological Station, Chinese Academy of Sciences.

\section{REFERENCES}

Brimblecombe, P., M. Tranter, P.W. Abrahams, I. Blackwood, T.D. Davies and C.E. Vincent. 1985. Relocation and preferential elution of acidic solute through the snowpack of a small, remote, high-altitude Scottish catchment. Ann. Glaciol., 7, 141-147.

Brimblecombe, P., S.L. Clegg, T.D. Davies, D. Shooter and M. Tranter. 1987. Observations of the preferential loss of major ions from melting snow and laboratory ice. Water Res., 21(10), $1279-1286$

Dibb, J.E. 1996. Overview of field data on the deposition of aerosol-associated species to the surface snow of polar glaciers, particularly recent work in Greenland. In Wolff, E.W. and R.C. Bales, eds. Chemical exchange between the atmosphere and polar snow. Berlin, etc., Springer-Verlag, 249-274. (NATO ASI Series I: Global Environmental Change 43.)

Eichler, A., M. Schwikowski and H.W. Gäggeler. 2001. Meltwaterinduced relocation of chemical species in Alpine firn. Tellus, 53B(2), 192-203.

Ginot, P., C. Kull, M. Schwikowski, U. Schotterer, B. Pouyaud and H.W. Gäggeler. 2001. Effects of post-depositional processes on snow composition of a subtropical glacier (Cerrado Tapado, Chilean Andes). J. Geophys. Res., 106(D23), 32,375-32,386.

Heather, A.R., S. Yi, N. Moumen, Y. Han and T. Holsen. 2004. Quantifying the dry deposition of reactive nitrogen and sulfur containing species in remote areas using a surrogate surface analysis approach. Atmos. Env., 38, 2687-2697.

Hou, S. and D. Qin. 1999. The ion elution effect on the main ion profiles of the glacier snowpacks. Chinese J. Geogr. Sci., 19(6), 536-542. [In Chinese with English summary.]

Hou, S. and D. Qin. 2002. The effect of postdepositional process on the chemical profiles of snow pits in the percolation zone. Cold Reg. Sci. Technol., 34(2), 111-116.

Hou, S., D. Qin and J. Ren. 1999. Different post-depositional processes of $\mathrm{NO}_{3}{ }^{-}$in snow layers in East Antarctica and on the northern Qinghai-Tibetan Plateau. Ann. Glaciol., 29, 73-76.

Hu, R. and F. Jiang. 1989. Control of avalanche hazard in the Tien Shan mountains, China. Beijing, People's Transportation Press. [In Chinese.]

lizuka, Y., M. Igarashi, K. Kamiyama, H. Motoyama and O. Watanabe. 2002. Ratios of $\mathrm{Mg}^{2+} / \mathrm{Na}^{+}$in snowpack and an ice core at Austfonna ice cap, Svalbard, as an indicator of seasonal melting. J. Glaciol., 48(162), 452-460.

Jiang, F., C. Zhu, W. Wei and O. Abe. 2002. Some results of snow chemical surveys in the Kunnes River valley, East Tienshan mountains, China. Atmos. Environ., 36(31), 4941-4949.

Kuhn, M., J. Haslhofer, U. Nickus and H. Schellander. 1998. Seasonal development of ion concentration in a high alpine snow pack. Atmos. Environ., 32(5), 4041-4051. 
Li, J.F. 1991. Climate in Xinjiang. Beijing, Meteorological Press. [In Chinese.]

Luo, H. 1983. Hydrochemical features of the Glacier No. 1 in the source region of Ürümqi River, Tian Shan. J. Glaciol. Geocryol., 5(2), 55-64. [In Chinese with English abstract.]

Maupetit, F. and 14 others. 1993. Chemical composition of Alpine glacier snow during 1991 SNOSP campaign: an overview of its spatial variability. In Borrell, P.M., P. Borrell, T. Cvitas and W. Seiler, eds. Proceedings of EUROTRAC Symposium '92. The Hague, SPB Academic Publishing, 757.

Maupetit, F., D. Wagenbach, P. Weddeking and R.J. Delmas. 1995. Seasonal fluxes of major ions to a high altitude cold alpine glacier. Atmos. Environ., 29(1), 1-9.

Neftel, A., A. Sigg and F. Zürcher. 1987. Acid deposition in a snow field at 2500 ma.s.l. in Switzerland. In Angletti, G. and G. Restelli, eds. Proceedings of the 4th European Symposium on the Physico-Chemical Behaviour of Atmospheric Pollutants. Dordrecht, etc., D. Reidel Publishing Co., 500-510.

Paterson, W.S.B. 1994. The physics of glaciers. Third edition. Oxford, etc., Elsevier.

Pohjola, V. and 7 others. 2002. Effect of periodic melting on geochemical and isotopic signals in an ice core on Lomonosovfonna, Svalbard. J. Geophys. Res., 107(D4), 4036. (10.1029/ 2000JD000149.)

Psenner, R. and U. Nickus. 1986. Snow chemistry of a glacier in the central eastern Alps (Hintereisferner, Tyrol, Austria). Z. Gletscherkd. Glazialgeol., 22(1), 1-18.

Puxbaum, H. 1989. ALPTRAC. EUROTRAC Annual Report, Part 3. Garmisch-Partenkirchen, Fraunhofer Institute for Atmospheric Environmental Research. Scientific Secretariat.

Qiu, J. 1993. Study on characters of snow climate in middle mountains of Western Tianshan with examples from valley of Kunnes River. In Geographical Symposium of Arid Zone, No. 3. Beijing, Science Press, 123-132. [In Chinese.]

Schotterer, U., W. Stichler and P. Ginot. 2004. The influence of post-depositional effects on ice core studies: examples from the Alps, Andes, and Altai. In Cecil, L.D., J.R. Green and
L.G. Thompson, eds. Earth paleoenvironments: records preserved in mid- and low-latitude glaciers. Dordrecht, etc., Kluwer, 39-60.

Schulz, O. and C. de Jong. 2004. Snowmelt and sublimation: field experiments and modelling in the High Atlas Mountains of Morocco. Hydrol. Earth Syst. Sci., 8(6), 1076-1089.

Shumskii, P.A. 1964. Principles of structural glaciology. New York, Dover Publications.

Stichler, W., U. Schotterer, K. Fröhlich, P. Ginot, C. Kull and H.W. Gäggeler. 2001. The influence of sublimation on stable isotope records recovered from high altitude glaciers in the tropical Andes. J. Geophys. Res., 106(D19), 22,613-22,620.

Tranter, M., S. Tsiouris, T.D. Davies and H.G. Jones. 1992. Laboratory investigation of the leaching of solute from snowpack by rainfall. Hydrol. Process., 6, 169-178.

Waddington, E.D., J. Cunningham and S.L. Harder. 1996. The effects of snow ventilation on chemical concentrations. In Wolff, E.W. and R.C. Bales, eds. Chemical exchange between the atmosphere and polar snow. Berlin, etc., Springer-Verlag, 403451. (NATO ASI Series I: Global Environmental Change 43.)

Winiwarter, W. and 6 others. 1998. Concentration of ionic compounds in the wintertime deposition: results and trends from the Austrian Alps over 11 years (1983-1993). Atmos. Environ., 32(23), 4031-4040.

Wolff, E.W. 1996. Location, movement and reactions of impurities in solid ice. In Wolff, E.W. and R.C. Bales, eds. Chemical exchange between the atmosphere and polar snow. Berlin, etc., Springer-Verlag, 541-560. (NATO ASI Series I: Global Environmental Change 43.)

Zhang, J. and Z. Deng. 1987. An introduction to Zinjiang precipitation. Beijing, Meteorological Press. [In Chinese.]

Zhang, Y., E. Kang and C. Liu. 1994. Mountain climate analysis in Ürümqi River valley, Tianshan. J. Glaciol. Geocryol., 16(4), 333-341. [In Chinese.]

Zhao, Z. and Z. Li. 2004. Determination of soluble ions in atmospheric aerosol by ion chromatography. Mod. Sci. Instrum., 5, 46-49. [In Chinese.] 